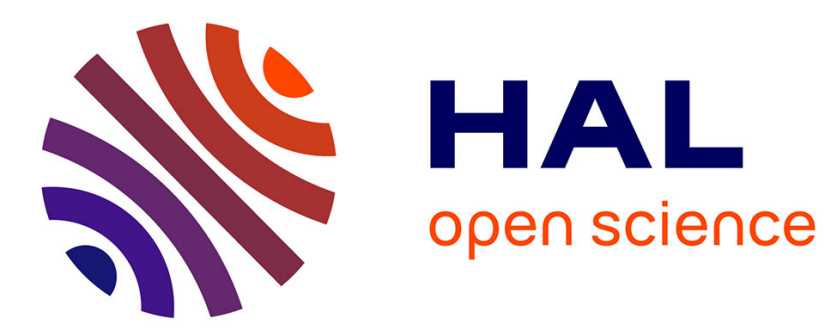

\title{
Positive effects of naringenin on near-surface membrane fluidity in human erythrocytes
}

\author{
V. Ajdzanovic, V. Jakovljevic, Dragan Milenkovic, A. Konic-Ristic, J. \\ Zivanovic, I. Jaric, V. Milosevic
}

\section{- To cite this version:}

V. Ajdzanovic, V. Jakovljevic, Dragan Milenkovic, A. Konic-Ristic, J. Zivanovic, et al.. Positive effects of naringenin on near-surface membrane fluidity in human erythrocytes. Acta Physiologica Hungarica, 2015, 102 (2), pp.131-136. 10.1556/036.102.2015.2.3 . hal-01214147

\section{HAL Id: hal-01214147 \\ https://hal.science/hal-01214147}

Submitted on 9 Oct 2015

HAL is a multi-disciplinary open access archive for the deposit and dissemination of scientific research documents, whether they are published or not. The documents may come from teaching and research institutions in France or abroad, or from public or private research centers.
L'archive ouverte pluridisciplinaire HAL, est destinée au dépôt et à la diffusion de documents scientifiques de niveau recherche, publiés ou non, émanant des établissements d'enseignement et de recherche français ou étrangers, des laboratoires publics ou privés. 


\title{
Positive effects of naringenin on near-surface membrane fluidity in human erythrocytes
}

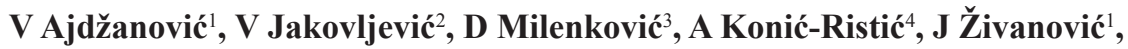 \\ I Jarić ${ }^{1}, \mathbf{V}$ Milošević ${ }^{1}$ \\ ${ }^{1}$ Institute for Biological Research "Siniša Stanković", University of Belgrade, Belgrade, Serbia \\ ${ }^{2}$ Faculty of Medical Sciences, Department of Physiology, University of Kragujevac, Kragujevac, Serbia \\ ${ }^{3}$ INRA, UMR1019, UNH, CRNH Auvergne, Clermont-Ferrand, Unité de Nutrition Humaine, Clermont Université, \\ Université d'Auvergne, Clermont-Ferrand, France \\ ${ }^{4}$ Center of Research Excellence in Nutrition and Metabolism, Institute for Medical Research, University of \\ Belgrade, Belgrade, Serbia
}

Received: December 8, 2014

Accepted after revision: February 21, 2015

\begin{abstract}
Purpose: Deformability/rheologic behavior of erythrocytes are related to near-surface membrane fluidity. Specific agents can increase erythrocyte membrane fluidity in order to adjust hemodynamics in cardiovascular diseases. Grapefruit flavanone naringenin has been proposed for potential use in an alternative therapy of cardiovascular conditions. In respect to this, we assessed here effects of two nutritionally relevant concentrations of naringenin $(0.1$ and $1 \mu \mathrm{g} / \mathrm{ml})$ on near-surface membrane fluidity in human erythrocytes. Methods: We used electron paramagnetic resonance spectroscopy and fatty acid spin probes (5-DS and 7-DS), the spectra of which are dependent on membrane fluidity. Results: The results showed a significant $(p=0.029)$ increase of membrane fluidity near the hydrophilic surface in erythrocytes treated with higher concentration of naringenin. In the deeper layer, just below the erythrocyte membrane phospholipid heads, both lower and higher concentration of naringenin significantly increased membrane fluidity ( $p=0.036$ and $p=0.028$, respectively). Conclusions: These data document the positive and dose dependent effect of naringenin on near-surface membrane fluidity in human erythrocytes, recommending its use in the cardiovascular conditions characterized by disturbed hemodynamics.
\end{abstract}

Keywords: naringenin, membrane fluidity, erythrocytes, cardiovascular

Flavanones are polyphenolic compounds that are present in the diet almost exclusively via citrus fruits. They are constituted of aromatic rings with one or more hydroxyl groups and they are usually glycosylated in the plant (6). The inverse relationship between human citrus consumption and the risk of cardio-/cerebrovascular diseases has been observed $(12,13)$. Numerous animal studies reported benefits of flavanone glycosides or aglycones application in normal vascular function maintenance and in hypertension (25), triglyceridemia and cholesterolemia (7), inflammation and atherosclerosis development (14) as well as to an oxidative stress $(11,15)$. Still, the mechanisms responsible for different flavanone actions are not completely elucidated.

It has been proposed that membrane tension/fluidity represents one of the crucial definers of the cell mechanical status $(4,5)$ and determines cell rheological properties $(26)$. When it comes to erythrocytes, these properties reflect their ability to elastically modify shape in order to functionally pass through the narrow vessels (26), especially in hypertension or

Corresponding author: Vladimir Ajdžanović, $\mathrm{PhD}$

Department of Cytology, Institute for Biological Research "Siniša Stanković”, University of Belgrade

142 Despot Stefan Blvd, 11060 Belgrade, Serbia

Phone: +381-11-2078-321; Fax: +381-11-2761-433; E-mail: avlada@ibiss.bg.ac.rs 
atherosclerosis. We have recently shown the linear dependence of erythrocyte deformability and superficial membrane fluidity, using the alcohols of rising molecular size in the model system (19). Also, the cell membrane alterations may characterize a certain blood pressure disorders (16). In this respect, it was observed that erythrocyte membrane fluidity is significantly lower in both spontaneously hypertensive rats and patients with essential hypertension, in comparison with normotensive subjects $(22,23,24)$. Obviously, the fatty acid profile of the erythrocyte membrane together with its biophysical properties may be at least partially responsible for some cardiovascular risks $(3,9)$. Considering that the polarity and the number and arrangement of functional groups in polyphenoles of natural origin determine their positioning in the membrane bilayer (4), the erythrocyte elastic deformation and, furthermore, hemodynamics may be variously affected upon their application.

The aim of our study was to determine if the flavanone aglycone naringenin (originated from grapefruit; the structure shown in Fig. 1) can increase near-surface erythrocyte membrane fluidity. Considering that superficial erythrocyte membrane fluidity is reflected in deformability and affects hemodynamics, such information might potentially recommend naringenin for hypertension and atherosclerosis treatment. We applied electron paramagnetic resonance (EPR) spectroscopy and 2 lipophilic (fatty acid) spin probes, 5- and 7-doxyl stearate (5-DS and 7-DS), being able to intercalate into membranes and whose EPR spectra are dependent on membrane fluidity. The 5-DS probe provided information on fluidity near the hydrophilic erythrocyte membrane surface, while the 7-DS probe has the EPR active structure with an unpaired electron at carbon 7 from the carboxyl group, thus signaling from just below the erythrocyte membrane phospholipid heads (21).

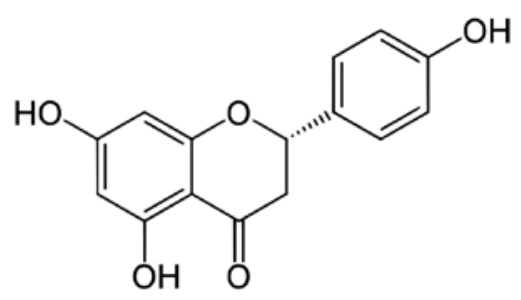

Fig. 1. The chemical structure of naringenin

\section{Materials and Methods}

Venous blood samples were obtained from four healthy volunteers, aged between 29 to 37 years, using vacuum tubes containing $0.072 \mathrm{~mL}$ of $7.5 \% \mathrm{~K}_{3}$ EDTA as the anticoagulant per 3 $\mathrm{mL}$ of blood (Vacuette EDTA; Greiner Bio-One, Kremsmünster, Austria). All procedures related to the use of human blood in this study are in conformity with the recommendation provided in The Code of Ethics of the World Medical Association (Declaration of Helsinki) for experiments involving humans. Experiment was completed within 4 hours following blood sampling. The erythrocytes (erythrocyte membranes) were spin-labeled as described previously $(1,2,3)$. In brief, erythrocytes were isolated from fresh blood and washed three times with phosphate buffered saline (PBS) by centrifugation at $3,500 \times g$ for $10 \mathrm{~min}$ at $4{ }^{\circ} \mathrm{C}$; the hematocrit in all samples was adjusted to $\sim 40 \%$. Ethanol solutions of spin-labels 5-DS and 7-DS (Sigma-Aldrich, Co., St. Louis, MO, USA) were applied onto the walls of microtubes, with the amount of DS calculated to obtain an optimal spin label to membrane 
lipid ratio of approximately 1:100. After the ethanol had evaporated from the DS, erythrocytes were added and gently mixed, and naringenin (Sigma-Aldrich, Co., St. Louis, MO, USA), dissolved in dimethyl sulfoxide (DMSO), was added to the erythrocytes in the microtubes to achieve final concentrations of 0.1 or $1 \mu \mathrm{g} / \mathrm{ml}$. Naringenin concentrations were chosen to mimic flavanone in vivo levels in the blood of humans daily consuming $180 \mathrm{~g}$ of fresh grapefruit $(0.1 \mu \mathrm{g} / \mathrm{ml} ; 6)$ or $8 \mathrm{ml}$ of grapefruit juice $/ \mathrm{kg}$ b.w. $(1 \mu \mathrm{g} / \mathrm{ml} ; 8)$ (lower and higher nutritional dose). Aliquots of DMSO were added to control samples. The final proportion of DMSO was $1 \%$ in all samples, and coagulation was absent during the procedure. Erythrocyte samples were placed in Teflon tubes with a wall thickness of $0.025 \mathrm{~mm}$ and an internal diameter of $0.6 \mathrm{~mm}$ (Zeus Industries, Raritan, NJ, USA) and inserted into quartz capillaries. Electron paramagnetic resonance (EPR) spectra at $20^{\circ} \mathrm{C}$ were recorded 4 min after the addition of naringenin solutions using a Varian E104-A EPR spectrometer (Palo Alto, CA, USA) operating at X-band $(9.1 \mathrm{GHz})$ with the following settings: modulation amplitude $=2$ $\mathrm{G}$; modulation frequency $=100 \mathrm{kHz}$; microwave power $=20 \mathrm{~mW}$; scan range $=100 \mathrm{G}$; scan time $=4 \mathrm{~min}$; time constant $=0.25 \mathrm{~s}$. Spectra were recorded and analyzed using EW software (Scientific Software Inc., Bloomington, IL, USA), and the order parameters (S) of 5-DS- and 7-DS-labeled erythrocytes, which are reciprocally proportional to fluidity, were calculated as described previously $(1,2,3)$. All experiments were performed at least in quadruplicate. The data are presented as means \pm standard deviation (SD). Significant differences were calculated by the non-parametric two-tailed Mann-Whitney test. Means were considered significantly different at $p<0.05$.

\section{Results}

Figure 2 presents the characteristic EPR spectra of 5- and 7-DS in the membrane of erythrocytes that were untreated or treated with naringenin. The calculated order parameters (S) of erythrocyte membrane labeled with 5-DS and 7-DS are summarized in Table I. Considering that the order parameter is reciprocally proportional to the membrane fluidity, a significant increase of membrane fluidity near the hydrophilic surface was detected in erythrocytes treated with higher concentration $(1 \mu \mathrm{g} / \mathrm{ml})$ of naringenin, while the lower concentration of naringenin $(0.1 \mu \mathrm{g} / \mathrm{ml})$ was ineffective $(p>0.05)$ in that membrane region. On the other hand, in the hydrophobic layer just below the erythrocyte membrane phospholipid heads both lower and higher concentration of naringenin significantly increased membrane fluidity.

\section{Discussion}

The present study suggests that naringenin increases near-surface membrane fluidity in human erythrocytes at lower $(0.1 \mu \mathrm{g} / \mathrm{ml})$ and higher $(1 \mu \mathrm{g} / \mathrm{ml})$ nutritionally-relevant concentration. Naringenin concentrations were chosen in order to mimic in vivo levels present in the blood of humans consuming $180 \mathrm{~g}$ of fresh grapefruit $(0.1 \mu \mathrm{g} / \mathrm{ml} ; 6)$ or $8 \mathrm{ml}$ of grapefruit juice/kg b.w. $(1 \mu \mathrm{g} / \mathrm{ml} ; 8)$. The current data imply that naringenin preferentially inserts into the hydrophobic layer just below the erythrocyte membrane phospholipid heads, where the molecular order is disturbed as well as the entropy increased upon its positioning, all of which results in an increased membrane fluidity. Obviously, the lower concentration of naringenin is not sufficient for the saturation of layer near the erythrocyte membrane hydrophilic surface, the flavanone molecules appear to rapidly pass through it and the effects pertinent to membrane fluidity remain absent. It is known that different substituents on the 

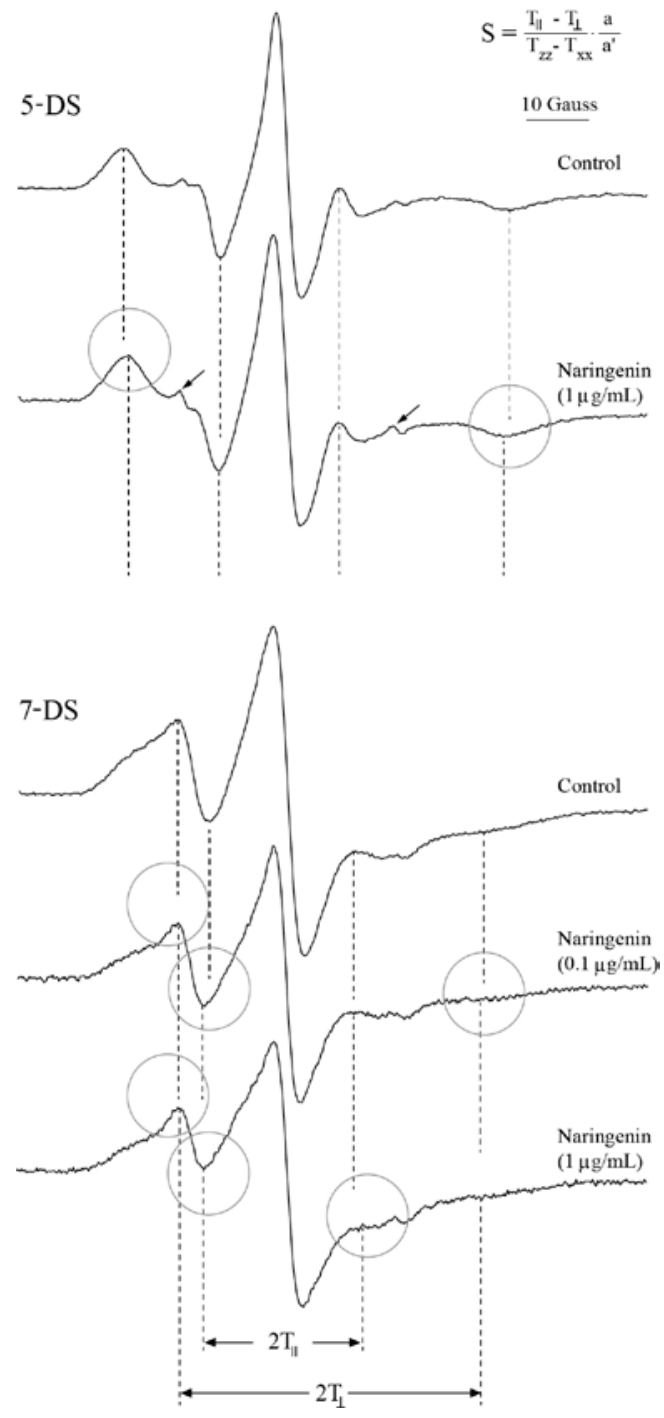

Fig. 2. Characteristic electron paramagnetic resonance (EPR) spectra of human erythrocytes labeled with 5-doxyl stearate (5-DS) without (control) or with naringenin $(1 \mu \mathrm{g} / \mathrm{mL})$ as well as of human erythrocytes labeled with 7-doxyl stearate

(7-DS) without (control) or with naringenin

$(0.1 \mu \mathrm{g} / \mathrm{mL}$ and $1 \mu \mathrm{g} / \mathrm{mL})$; $\mathrm{S}$, order parameter; $2 \mathrm{~T}_{\mathrm{II}}$, outer hyperfine splitting; $2 \mathrm{~T}_{\perp}$, inner hyperfine splitting; a, isotropic hyperfine coupling constant in

crystal $\left[a=1 / 3\left(T_{x x}+T_{y y}+T_{z z}\right)\right] ; a$, isotropic

hyperfine coupling constant in membrane

$\left[\mathrm{a}^{\prime}=1 / 3\left(\mathrm{~T}_{\mathrm{II}}+2 \mathrm{~T}_{\perp}\right)\right] ; \mathrm{T}_{\mathrm{xx}}, \mathrm{T}_{\mathrm{yy}}, \mathrm{T}_{\mathrm{zz}}$, hyperfine constants (for 5-DS and 7-DS they were taken to be $\left.\mathrm{T}_{\mathrm{xx}}=\mathrm{T}_{\mathrm{yy}}=6.1 \mathrm{G}, \mathrm{T}_{\mathrm{zz}}=32.4 \mathrm{G}\right)(10)$. Dashed lines marking parameters in control spectra, are shown in order to stress the differences between controls and treated samples. Pale circles point up order parameter-relevant differences between control spectra and spectra acquired for treated erythrocytes. Two narrow lines originate from the DSs in the solution (arrows) $(10,20)$

Table I. Order parameters (S) of 5-doxyl stearate (5-DS) or 7-doxyl stearate (7-DS) -labeled membranes of human erythrocytes exposed to naringenin

\begin{tabular}{|c|c|c|c|}
\hline & Controls & $\begin{array}{c}\text { Naringenin } \\
(0.1 \mu \mathrm{g} / \mathrm{ml})\end{array}$ & $\begin{array}{c}\text { Naringenin } \\
(1 \mu \mathrm{g} / \mathrm{ml})\end{array}$ \\
\hline $\mathrm{S}(5-\mathrm{DS})$ & $0.746 \pm 0.002$ & $\begin{array}{c}0.743 \pm 0.011 \\
\text { (n.s.) }\end{array}$ & $\begin{array}{c}0.735 \pm 0.009 * \\
(p=0.029)\end{array}$ \\
\hline $\mathrm{S}(7-\mathrm{DS})$ & $0.615 \pm 0.006$ & $\begin{array}{c}0.580 \pm 0.003^{*} \\
(p=0.036)\end{array}$ & $\begin{array}{c}0.579 \pm 0.002 * \\
\quad(p=0.028)\end{array}$ \\
\hline
\end{tabular}

Data are shown as means \pm SD. S, order parameter of the membrane; 5-DS and 7-DS, fatty acid spin probes; n.s. - not statistically significant; * significantly different relative to corresponding controls (dissolvent - dimethyl sulfoxide (DMSO) treated erythrocytes, $1 \mu 1 \mathrm{DMSO} / 100 \mu 1$ of blood) 
polyphenole molecules of natural origin dominantly influence their physicochemical properties and thus determine the partitioning into membrane bilayer (18). Considering the naringenin hydrophobicity on the one hand and the presence of polar hydroxyl groups on the other (17), its incorporation into the membrane and near the polar surface could be expected. It is important to note that flavanones show a notable capability for transverse motions in cell membrane (18), wherein their dosage may play a role.

In conclusion, according to the ability of naringenin to increase near-surface membrane fluidity which is reflected positively in their deformability and rheologic behavior $(19,26)$, our results imply potentially beneficial effects of citrus flavanone intake in the conditions characterized by decreased luminal diameter of blood vessels and disturbed hemodynamics.

\section{Acknowledgements}

This work was supported by the Ministry of Science, Education and Technological Development of the Republic of Serbia, Grant number 173009. We wish to express our gratitude to Ivan Spasojević PhD, Life Systems Department, Institute for Multidisciplinary Research, Belgrade, Serbia for the valuable methodological and intellectual assistance during the experiments and manuscript preparation.

\section{Conflict of Interest}

The authors declare that they have no conflict of interest.

\section{REFERENCES}

1. Ajdžanović V, Spasojević I, Filipović B, Šošić-Jurjević B, Sekulić M, Milošević V: Effects of genistein and daidzein on erythrocyte membrane fluidity: an electron paramagnetic resonance study. Can. J. Physiol. Pharmacol. 88, 497-500 (2010)

2. Ajdžanović V, Spasojević I, Šošić-Jurjević B, Filipović B, Trifunović S, Sekulić M, Milošević V: The negative effect of soy extract on erythrocyte membrane fluidity: an electron paramagnetic study. J. Membrane. Biol. 239, 131-135 (2011)

3. Ajdžanović V, Spasojević I, Pantelić J, Šošić-Jurjević B, Filipović B, Milošević V, Severs W: Vitex agnus-castus L. essential oil increases human erythrocyte membrane fluidity. J. Med. Biochem. 31, 222-227 (2012)

4. Ajdžanović V, Medigović I, Pantelić J, Milošević V: Soy isoflavones and cellular mechanics. J. Bioenerg. Biomembr. 46, 99-107 (2014)

5. Asnacios A, Hamant O: The mechanics behind cell polarity. Trends Cell. Biol. 22, 584-591 (2012)

6. Chanet A, Milenkovic D, Manach C, Mazur A, Morand C: Citrus flavanones: what is their role in cardiovascular protection? J. Agric. Food Chem. 60, 8809-8822 (2012)

7. Cho KW, Kim YO, Andrade JE, Burgess JR, Kim YC: Dietary naringenin increases hepatic peroxisome proliferators-activated receptor alfa protein expression and decreases plasma triglyceride and adiposity in rats. Eur. J. Nutr. 50, 81-88 (2011)

8. Erlund I, Meririnne E, Alfthan G, Aro A: Plasma kinetics and urinary excretion of the flavanones naringenin and hesperetin in humans after ingestion of orange juice and grapefruit juice. J. Nutr. 131, 235-241 (2001)

9. Funari SS, Barcelo F, Escriba PV: Effects of oleic acid and its congeners, elaidic and staric acids, on the structural properties of phosphatidylethanolamine membranes. J. Lipid Res. 44, 567-575 (2003)

10. Gaffney BJ (1976): Practical considerations for the calculation of order parameters for fatty acids or phospholipid spin labels in membranes. In: Spin Labeling, Theory and Applications, eds. Berliner LJ, Academic Press, New York, pp. 567-571

11. Jeon SM, Bok SH, Jang MK, Kim YH, Nam KT, Jeong TS, Park YB, Choi MS: Comparison of antioxidant effects of naringin and probucol in cholesterol-fed rabbits. Clin. Chim. Acta 317, 181-190 (2002) 
12. Joshipura KJ, Ascherio A, Manson JE, Stampfer MJ, Rimm EB, Speizer FE, Hennekens CH, Spiegelman D, Willett WC: Fruit and vegetable intake in relation to risk of ischemic stroke. JAMA - J. Am. Med. Assoc. 282, 1233-1239 (1999)

13. Joshipura KJ, Hu FB, Manson JE, Stampfer MJ, Rimm EB, Speizer FE, Colditz G, Ascherio A, Rosner B, Spiegelman D, Willett WC: The effect of fruit and vegetable intake on risk for coronary heart disease. Ann. Intern. Med. 134, 1104-1114 (2001)

14. Lee CH, Jeong TS, Choi YK, Hyun BH, Oh GT, Kim EH, Kim JR, Han JI, Bok SH: Anti-atherogenic effect of citrus flavonoids, naringin and naringenin, associated with hepatic ACAT and aortic VCAM-1 and MCP-1 in high cholesterol-fed rabbits. Biochem. Biophys. Res. Commun. 284, 681-688 (2001)

15. Lee MK, Bok SH, Jeong TS, Moon SS, Lee SE, Park YB, Choi MS: Supplementation of naringenin and its synthetic derivative alters antioxidant enzyme activities of erythrocyte and liver in high cholesterol-fed rats. Bioorg. Med. Chem. 10, 2239-2244 (2002)

16. Postnov YV, Orlov S: Cell membrane alteration as a source of primary hypertension. J. Hypertens. 2, 1-6 (1984)

17. Recourt K, van Brussel AA, Driessen AJ, Lughtenberg BJ: Accumulation of a nod gene inducer, the flavonoid naringenin, in the cytoplasmic membrane of Rhisobium leguminosarum biovarviciae is caused by the $\mathrm{pH}-$ dependent hydrophobicity of naringenin. J. Bacteriol. 171, 4370-4377 (1989)

18. Scheidt HA, Pampel A, Nissler L, Gebhardt R, Huster D: Investigation of the membrane localization and distribution of flavonoids by high-resolution magic angle spinning NMR spectroscopy. BBA - Biomembranes 1663, 97-107 (2004)

19. Sonmez M, Ince HY, Yalcin O, Ajdžanović V, Spasojević I, Meiselman HJ, Baskurt OK: The effect of alcohols on red blood cell mechanical properties and membrane fluidity depends on their molecular size. PloS One 8 , e76579 (2013)

20. Spasojević I, Maksimović V, Zakrzewska J, Bačić G: Effects of 5-fluorouracil on erythrocytes in relation to its cardiotoxicity: membrane structure and functioning. J. Chem. Inf. Model 45, 1680-1685 (2005)

21. Spasojevic I: Free radicals and antioxidants at a glance using EPR spectroscopy. Crit. Rev. Clin. Lab. Sci. 48: 114-142 (2011)

22. Tsuda K, Iwahashi H, Minatogawa Y, Nishio I, Kido R, Masuyama Y: Electron spin resonance studies of erythrocytes from spontaneously hypertensive rats and humans with essential hypertension. Hypertension 9 , 19-24 (1987)

23. Tsuda K: Oxidative stress and membrane fluidity of red blood cells in hypertensive and normotensive men. An electron spin resonance investigation. Int. Heart J. 51, 121-124 (2010)

24. Tsuda K: Associations between high-sensitivity C-reactive protein and membrane fluidity of red blood cells in hypertensive elderly men: an electron spin resonance study. Int. J. Hypertens. 2012, 292803 (2012)

25. Yamamoto M, Suzuki A, Hase T: Short-term effects of glucosyl hesperidin and hesperetin on blood pressure and vascular endothelial function in spontaneously hypertensive rats. J. Nutr. Sci. Vitaminol. (Tokyo) 54, 95-98 (2008)

26. Zicha J, Kunes J, Devynck MA: Abnormalities of membrane function and lipid metabolism in hypertension. Am. J. Hypertens. 12, 315-331 (1999) 